\title{
Preparing Students for Social Action in a Social Justice Education Course: What Works?
}

Stephanie Burrell Storms

Fairfield University, sstorms@fairfield.edu

Follow this and additional works at: https://digitalcommons.fairfield.edu/education-facultypubs Copyright 2012 Taylor \& Francis (Routledge)

The author's post-print version has been archived here with the permission of the copyright holder.

\section{Repository Citation}

Burrell Storms, Stephanie, "Preparing Students for Social Action in a Social Justice Education Course: What Works?" (2012). GSEAP Faculty Publications. 115.

https://digitalcommons.fairfield.edu/education-facultypubs/115

\section{Published Citation}

Storms, Stephanie Burrell. "Preparing Students for Social Action in a Social Justice Education Course: What Works?." Equity \& Excellence in Education 45, no. 4 (2012): 547-560. DOI: 10.1080/10665684.2012.719424

This item has been accepted for inclusion in DigitalCommons@Fairfield by an authorized administrator of DigitalCommons@Fairfield. It is brought to you by DigitalCommons@Fairfield with permission from the rightsholder(s) and is protected by copyright and/or related rights. You are free to use this item in any way that is permitted by the copyright and related rights legislation that applies to your use. For other uses, you need to obtain permission from the rights-holder(s) directly, unless additional rights are indicated by a Creative Commons license in the record and/or on the work itself. For more information, please contact digitalcommons@fairfield.edu. 


\title{
PREPARING STUDENTS FOR SOCIAL ACTION IN A SOCIAL JUSTICE EDUCATION \\ COURSE: WHAT WORKS?
}

\author{
Stephanie Burrell Storms* \\ Fairfield University
}

\begin{abstract}
The purpose of this study was to explore students' perceptions of how the curriculum and teaching strategies in a social justice education course prepared them for social action engagement. Past studies using a similar approach to teaching about social justice issues did not include student interviews. Students' perspectives can shed light on how experiences in a social justice education course prepared them to challenge social oppression and work toward equity in their daily lives. Six students were interviewed one semester after they completed a social justice education course. Findings indicated teaching strategies (e.g., experiential activities) that included students' lived experiences increased their personal awareness, empathy, confidence, and knowledge about tools for social action. These teaching strategies were identified more often than content as key in preparing students to take action. Classroom implications are discussed.
\end{abstract}

Due to the increased ethnic, religious, and linguistic diversity of the United States, college students must develop the knowledge, attitudes, and skills necessary to live and participate effectively as global citizens in a complex democracy. Checkoway (2001) argues, "Students

\footnotetext{
* Address correspondence to: Stephanie Burrell Storms, Educational Studies and Teacher Preparation, Fairfield University, 1073 North Benson Road, Fairfield, CT 06824. Email: sstorms@ fairfield.edu
} 
must be prepared to understand their own identities, communicate with people who are different from themselves and build bridges across cultural differences" for our democracy to function successfully in the future (p. 127). While many educators might agree with Checkoway, there is evidence that Americans continue to live segregated lives in the United States. For example, most students attend schools with peers of their same racial and social class backgrounds (Orfield \& Lee, 2006). Lack of experience with diversity can cause misunderstandings among social groups, especially if the information learned about one another comes from unreliable sources that perpetuate stereotypes, prejudice, and bias. Students may intentionally or unintentionally engage in harmful acts of bullying, sexist and racist humor, or derogatory "theme" parties without knowing how these incidents perpetuate social oppression. In the undergraduate social justice education course I teach, my goal is to increase students' knowledge, skills, self-confidence, and motivation to engage in social action and confront challenging social issues when they arise in their daily lives.

There is a growing number of studies that examine the relationship between student enrollment in social justice education courses and action-oriented outcomes (Alimo, 2012; Nagda, Kim, \& Truelove, 2004; Nelson Laird, Engberg, \& Hurtado, 2005; Pittman, 2009; Zúñiga, Williams, \& Berger, 2005). Findings from these studies indicate that students who enrolled in social justice education courses are more confident and committed to social action and showed greater behavioral intentions or actual social action behaviors by the end of the course. Quantitative methods were used in all of the studies to date to investigate the impact of social justice education courses on students' social action engagement. I use qualitative methods, interviews to glean students' perspectives on how the practice in a social justice education course prepared them for social action. 
I am a social justice educator who is committed to preparing students for positive social engagement with issues of social justice and diversity. I attempt to prepare students for this role in two ways: as a classroom educator and researcher. Through this study I explore students' perceptions of the curriculum and practice in a social justice education course and its role in preparing them for social action outside the classroom. Although research outcomes are linked to practice, I separate them here to maintain focus. First, in this article, I describe the literature that examines the relationship between student enrollment in social justice education courses and action-oriented outcomes; second, I discuss the practice and context in which this study is based. Finally, I conclude with a brief discussion of my findings and their implications for teaching social justice education courses.

\section{SOCIAL ACTION ENGAGEMENT}

Nelson Laird, Engberg, and Hurtado (2005) describe social action engagement as students' willingness to "take actions in their communities and relationships in order to end social injustice" (p. 468). Several scholars suggest that social action can be self-oriented (e.g., confronting one's prejudice), other-directed (e.g., challenging others on derogatory jokes), or collaborative (e.g., joining an organization to end poverty) (Alimo, 2012; Zúñiga et al., 2005). The focus of social action can take place at the micro-level (interpersonal) and macro-level (institutional) (Hardiman, Jackson, and Griffin, 2007). Promoting diversity and social justice have also been identified as examples of social action in the literature (Nagda et al., 2004;

Pittman, 2008; Zúñiga et al., 2005). Social action in this sense is different from civic engagement which focuses on voting or community service (Zúñiga et al., 2005). For the purposes of this article, I define social action engagement as students' ability to recognize and respond to the "isms" (e.g., classism, racism, sexism, etc.), individually and collectively, in their daily lives. 
Examples include, but are not limited to, incidents such as bullying, sexual harassment, and racial profiling.

The literature examining the relationship between social justice education and actionoriented outcomes is beginning to emerge. Studies have shown that students enrolled in social justice education courses increase their commitment and confidence to take action (Gurin-Sands, Gurin, Nagda, \& Osuna, 2012; Nagda et al., 2003; Nagda et al., 2004; Nagda, Gurin, Sorenson, Gurin-Sands, \& Osuna, 2009) and place greater importance on social action engagement (Nelson Laird et al., 2005). In one study, students were more likely to select macro-level actions to address a social justice incident as opposed to identifying the target of discrimination as the problem (Lopez, Gurin, \& Nagda, 1998). In other studies, students were more motivated to engage in self-oriented and other-oriented actions (Zúñiga et al., 2005) and reported engaging in social action behaviors more often than the control group (Stake \& Hoffman, 2001). However, in one study, students' social action intentions did not change over the course of one semester (Pittman, 2009). Mixed results were found in a recent study that examined the impact of a “racism-themed intergroup dialogue course on white college students' confidence and frequency in taking" self-directed, other-directed, and collaborative actions (Alimo, 2012, p. 37). While students enrolled in the dialogue course reported taking action more often than the control group, there was no difference found between the two groups' confidence level for social action engagement (Alimo, 2012).

In three of the above-referenced studies, the pedagogy (i.e., active learning techniques and dialogue) had a greater impact on students' commitment to social action during one semester than did the course content (Nagda et al, 2003; Nagda et al., 2009; Gurin-Sands et al., 2012). However, a different study found that both the course content and pedagogy increased students' 
confidence and willingness to engage in other-directed actions by the end of the course, but not self-directed ones (Nagda et al., 2004).

Overall, the research suggests a positive relationship between students' enrollment in social justice education courses and action-oriented outcomes. However, studies specifically exploring how the content or pedagogy prepares students for social action engagement is limited. I build on this literature by using qualitative methods. I asked students directly, in individual interviews, how they experienced the curriculum and pedagogy in a social justice education course and their perception of how the practice used prepared them to engage in social action. An advantage of interviewing is that the researcher can ask participants follow-up questions to their initial responses to further understand the how and why of a particular experience — this is difficult to do when administering a survey with fixed responses (Seidman, 2006). While this study does not claim a causal relationship between students' enrollment in a social justice education course and their development on action-oriented outcomes, I contend it is valuable to explore whether students felt greater readiness to take action and investigate how they developed the knowledge, skills, self-confidence, and motivation to do so while enrolled in a social justice education course.

\section{SOCIAL JUSTICE EDUCATION}

Social justice education (SJE) is an educational reform movement to increase equity across social groups locally and globally (Carlisle, Jackson, \& George, 2006). This approach examines how social institutions, such as P-12 schools, have historically reproduced social inequality among marginalized groups and provided privilege to dominant groups (Bell, 2007). Marginalized groups in the U.S. tend to have less access to power and resources needed to participate fully in society, while dominant groups have greater access to power and resources 
necessary to get their daily needs met (Hardiman et al., 2007). For this reason, scholars argue that it is necessary to provide students with the knowledge and skills to critique and challenge social institutions to live up to our democratic values of equal access and opportunity for all citizens (Banks, 2010).

One of the primary goals of SJE is to provide students with the knowledge and skills necessary to become agents of change (Grant \& Sleeter, 2010). Educational programs that prefer this approach implement curriculum ${ }^{1}$ that is interdisciplinary and includes diverse sociocultural viewpoints about social oppression. In addition, the curriculum focuses on the interlocking system of oppression (i.e., racism, sexism, classism, heterosexism, religious oppression, ableism, and adultism) that occurs on a micro-level (individual attitudes and behaviors), cultural (values and beliefs), and macro-level (institutional policies and practices) (Hardiman, Jackson, \& Griffin, 2007). The pedagogy, drawn from experiential learning theory and active teaching methods (Adams \& Marchesani, 1997), incorporates strategies that reflect its social justice goals: “collaborative, democratic, participatory, and inclusive" (Adams, 2010, p. 1036). For the purposes of this study, I focus on social action and what students learned and experienced in a SJE course that prepared them to recognize and confront the "isms" at both the micro and macro levels outside the classroom.

Hackman (2005) emphasized five principles of social justice education practice that I contend are necessary to prepare students for social action engagement: content mastery, tools for critical analysis, tools for personal reflection, tools for social action, and multicultural group dynamics. Content mastery pertains to the factual knowledge needed for students to recognize the "isms" in their daily lives (Adams \& Marchesani, 1997). Tools for critical analysis and personal reflection provide students with skills to question and challenge their own thinking, 
other students, and policies and practices in schools that contradict democratic ideals of justice and equity. Tools for social action refers to teaching students about the myriad ways citizens have created change in the United States. Learning about the process of change and steps to enact change can affect students' ability to identify and effectively apply action strategies to acts of social oppression.. Awareness of multicultural group dynamics illuminates the importance of intergroup interactions among students in social justice education courses (Adams, 2007). To increase the likelihood of students acting as allies for one another and engaging in collaborative action outside the classroom, social justice educators must implement strategies to help students build bridges across their cultural differences. In the next section, I provide details about the course and the procedures used in this study.

\section{CONTEXT FOR THE STUDY}

The SJE course in this study is an undergraduate, general education course that is taught by graduate students at a flagship university in the Northeast. The learning goals for the course are to increase students' understanding and awareness of structural inequality and to prepare them to recognize and confront acts of social oppression in their daily lives (Bell \& Griffin, 2007). The content covers multiple forms of social oppression (racism, sexism, classism, heterosexism, religious oppression, ableism, and adultism) and their connection to one another to provide students with the factual knowledge needed to identify and address these issues within their sphere of influence (Hackman, 2005). Each "ism" is examined at the individual, cultural, and institutional level for students to understand the focus of social action (Hardiman, Jackson, \& Griffin, 2007). The pedagogy used in this course attends to both affective and cognitive outcomes, encourages students to make connections between their personal experiences and societal issues discussed in the classroom, focuses on intergroup interactions, and promotes 
praxis (Adams, 2010). Myriad course activities (e.g., simulations, journals, lectures, action projects) are used for students to become social critics (Banks, 2010), reflect on their personal biases, and learn to develop action plans (Hackman, 2005), all of which, I argue, are necessary skills for social action engagement. In addition, dialogue, an integral component of this course, provides opportunities for marginalized and privileged groups to learn from one another and collaborate as allies to work toward social justice (Mayhew \& Fernández, 2007).

As a classroom instructor I heard student anecdotes during class discussions and read in their reflective papers encouraging accounts of what they felt worked in the classroom to prepare them for social action engagement. The findings from the social action engagement literature suggest that students are more confident and committed to social action (Gurin-Sands et al., 2012; Nagda et al., 2003; Nagda et al., 2004; Nagda et al., 2009; Nelson Laird et al., 2005) and showed greater behavioral intentions or actual social action behaviors (Alimo, 2012; Stake \& Hoffman, 2001; Zúñiga et al., 2005) after enrolling in SJE courses. In addition, a few studies found that the pedagogy (Gurin-Sands et al., 2012; Nagda et al., 2003; Nagda et al., 2009) or both the content and pedagogy (Nagda et al., 2004) were the primary mediators in helping students meet the course goals. These findings were useful in understanding what impact the course may have in preparing students for social action engagement and how the course processes play a role. Building on the literature and what students shared in the classroom, I decided to explore from their perspective what enabled them to have the knowledge, skills, selfconfidence, and motivation to confront issues they seemed oblivious to in their daily lives prior to taking the course.

\section{METHODS}


The findings discussed in this study are based on a larger study ${ }^{2}$ that used a mixed method design including social justice vignettes and interviews (Burrell, 2008). I report on the interviews only as they provide student reflections on their readiness for social action engagement. During the administration of the post-test for the larger study, students were asked to sign a release form giving me permission to contact them for an interview. The sample included six students who participated in the larger study and represented diverse social groups. In addition, the students represented two sections (six total) of the course offered that semester. There were three women and three men, of whom were four students of color and two were Caucasian students. Five students identified as sophomores and one as a junior. Three students had enrolled in similar SJE courses previously, while three had not. All were given pseudonyms to protect their identities. See Table 1 for student demographics.

\section{Procedures}

I conducted in-depth, individual interviews one semester after (Fall 2006) students enrolled in the SJE course (Spring 2006) to give them more time to process their course experiences. The interviews were approximately 60-90 minutes and a semi-structured protocol was used. The questions focused primarily on students' experiences in the social justice education course (e.g., If you had to describe your experience(s) in this course to a friend, what would you say?) and their understanding of how those experiences prepared them for social action engagement (e.g., In your opinion, how has the course helped you prepare to take social action?)

Data analysis followed the six-stage process described by Rossman and Rallis (2003) for data reduction, interpretation, and sense-making. To organize the data, the interviews were transcribed. I listened to the interviews and read the transcripts several times to become familiar with the data. Brackets were placed around meaningful passages to unitize the data and begin 
generating categories. Open coding was used to identify themes (Patton, 2002). To assess the trustworthiness of the themes identified and consider alternative categories, a peer reviewer was used for "check-coding" (Miles \& Huberman, 1994; Patton, 2002). In addition, all transcripts were sent to participants to proofread before excerpts were included in this article. Role of the Researcher

Creswell (2008) recommends that those who use qualitative methods to investigate phenomena identify their personal values and biases that could influence how the findings from a study are understood. A major assumption underlying this study is that through education and collaboration citizens can reduce structural inequality and increase equity in social institutions in the United States. I believe SJE courses can serve as effective interventions on college campuses to help students examine their own biases and learn effective action strategies for social change. I taught the course used in this study for two years prior to this study. This experience provided me with detailed information about the components of the course. When students presented their stories during the interviews, their descriptions of course processes and activities were familiar to me. This familiarity may have strengthened my understanding of students' experiences in ways that a researcher who has never taught diversity courses may deem insignificant. However, my prior experience with the course could interfere with my ability to uncover nuances in the data. To reduce bias and diminish the impact of my position as instructor (e.g., students providing favorable responses for good grades) with students, the classes of other instructors were used for this study.

\section{IN THE STUDENTS' VOICES}

Five major themes emerged from the interview data. All of the students could identify specific experiences in the course they believed best prepared them for action. The pedagogy 
(i.e., experiential activities) was identified more often than the course content when students reflected on their readiness for social action engagement. The themes derived from the interview data include class experiences that (1) brought students' lived experiences into the classroom, (2) raised students' personal awareness, (3) helped them develop greater empathy toward oppressed groups, (4) increased their confidence to engage in social action, and (5) proffered tools for action. Below are examples of student responses that reflect the themes derived from the interview data.

\section{Lived Experiences}

Encouraging students to share their personal experiences can be used as a starting point to examine the mechanics of oppression when done in a safe environment (Griffin \& Ouellette, 2007). Almost all students (five out of six) described how learning about other students' experiences with social oppression helped them identify racism, sexism, and other forms of oppression in their daily lives. Incorporating students' narratives into course activities is a form of honoring their voices. Voice is grounded in students' lived experiences and provides them with the opportunity to connect abstract concepts with real life (Adams, 2007). This approach can be best described as "collective inquiry into social reality" (Nagda et al., 2003, p. 169). Once students heard what their classmates experienced and began to reflect on those experiences, they were able to recognize racism, sexism, and other forms of oppression during class discussions and outside of the classroom — a precursor for taking action (Adams \& Marchesani, 1997). Ryan described that process in the following statement:

In the beginning a lot of people weren't talking, but by the end they were and brought up instances in their lives. We were like, "Oh yeah that's an instance of racism or socialization." People really changed and the more they opened up, they would tell 
people about what happened in their lives. Everyone kind of trusted one another because we are all learning together. That was pretty eye opening at the end. I guess that was pretty strong for me to talk about how you feel emotionally.

In addition, Oscar describes how the lived experiences of his classmates helped him understand how people from different social groups experienced oppression:

I think by taking this class I learned a lot about subjects I just knew from the outside. I just kind of heard about but never went into detail. Sexism, racism, I'm a Hispanic; I grew up in Boston. I have a sense of what it is, but I learned about people's other experiences in other parts of the countries, real life experiences, that go on every day.

\section{Personal Awareness}

All of the students in this study provided information indicating increased self-awareness. Students either discussed how a course process or activity increased their personal awareness or helped them become more aware about issues of social justice. Increased awareness about social inequality may increase students' commitment to social action engagement. In the following examples, two students describe how the course prepared them to take action. In the first example, Erica describes how the course readings challenged her thinking about social groups that could prevent her from taking action:

The one I really didn't have anything to say [about] was heterosexism because I really didn't even notice it. The green book $^{3}$, articles from that, made me question a lot of things I thought. My whole outlook on heterosexism and homosexuals just kind of changed. I looked at it kind of different because I am Christian, so I didn't accept it, and I felt like the fact that I would tolerate it would be okay and even just that- that is what changed my mind. ... I can't really see myself as someone who doesn't accept somebody. 
Ryan described how an activity made him more aware about sexism and how it influenced him to take action and change his behavior toward women:

We had to go through magazines [and look] for examples [of] sexual exploitations. You realize walking around on campus trying not to stare so hard at women because you don't realize how much pressure gets put on women. That could be taking action as subtle as it is. I guess that is a component because you realize how exploited women are. You have Maxim magazines, and you have clothing styles, etc. Relationships with women—trying not to call women bitches [or] sluts—even as a joke. You don't want to do that even as an acquaintance. Watching your language, be careful about what you are going to say. You don't want to hurt anyone.

\section{Empathy}

Almost all (five out of six) students gave responses that reflected empathy. According to McAllister and Irvine (2002), an empathic person is willing to "take on the perspective of another culture and respond to another individual from that person's perspective" (p. 433). For example, when a student was asked how the social justice education course prepared them to take action, Dina described how one activity helped her develop empathy toward an oppressed group:

A coming out letter to write to your best friend or family member if you were a lesbian. That helped me get into their shoes, and we had to write the other persons reaction. We had to put ourselves in other people's shoes.

Kevin described another activity in the course that helped him develop empathy for individuals going through the coming out process: 
We did an exercise on heterosexism when we had to write down our family and our favorite possession and then our friends and things like that and then we had to go through a story of what had happened if you're homosexual and people start acting against you and you lost everything.... It was really hard hitting. I completely respect [LGBT] people now, especially the ones that are open about it. So many people aren't aware or empathetic, people that go out of their way to make peoples' lives harder. It's the most unfair thing to me.

Being able to take on the perspective of oppressed groups may be a needed skill for social action engagement. Having to take on someone else's perspective may prepare students to become allies who can confront acts of oppression against target groups even when their voices are absent.

\section{Confidence}

All of the students who participated in the interviews provided statements that indicated increased self-confidence with taking social action. Self-confidence can influence a person's willingness to engage in a particular behavior (Nagda et al., 2004). If this is the case, we social justice educators must design activities for students to practice social action in a safe environment where they can increase their self-confidence and as Ryan stated, "realize nothing bad is going to happen to you." In the following student reflections, each described how the course increased their confidence to engage in social action. Both stated that gaining more information about social justice issues increased their confidence and prepared them for social action engagement. Dina described how reading about certain topics for class motivated her to take action: 
I have confidence now—that helps. The class itself helped me because it gave me a chance to see what people go through, I read stories about a gay guy being beaten and killed for his orientation. Knowing these stories are out there and happening to people make me want to take action.

Erica reported that encouragement from her instructor to speak out and gain more knowledge about social justice issues helped her feel more confident to take action. She stated,

Being encouraged to speak is one thing. Having a teacher who really encouraged feeding your mind, I take that from the class and just go on with it in the world basically; it helps me to encourage other people to do the same. There were certain issues that I really didn't know too much about. I was kind of hesitant to even take action. Just gaining more understanding on certain issues changed my outlook. [For example], seeing how there are people who don't have the same rights or privileges that I do. It was like even though I'm black there are still people that are more unprivileged than I am. That and just gaining more understanding about that helps me. It just gave me a very different outlook on things so now I feel more confident in talking about that instead of just living in my own ignorance.

\section{Tools for Action}

All of the students discussed how learning to take action in the course prepared them for social action engagement. According to Hackman (2005), it is "critical to help students move from cynicism and despair to hope and possibility when discussing issues of oppression" (p. 106). Teaching students about different approaches to social action is one way to move students toward the possibilities of social change. Students mentioned several strategies when asked which components of the course prepared them for social action engagement. For example, 
learning to critique or challenge oppression by finding their voice (speaking out in class and with friends), through writing, and developing action plans. When asked what prepared her for social action engagement, Nancy reflected on how receiving feedback on her action plan from classmates and the professor gave her confidence:

At the end of class we did this action plan. The presenter would stand in front of class and tell what you learned [and] what you are planning to continue to do. Then the audience would tell the person how they have affected them. That definitely builds confidence. Hearing [the instructor] tell me that he valued my writing. It builds confidence. I thought if I had the power to move [the instructor] with my writing, then maybe I could do something in the [school newspaper]. And what the audience did was gave you feedback. It was definitely a confidence-builder.

The following examples illustrate how modeling social action engagement may help students develop change agency ${ }^{4}$ and provide them with tools to use when an opportunity to take action arises. Oscar reflected on a video presentation in class:

A movie we saw about a white guy and a black guy in the South. The white guy would apply for the job, and the black guy would apply for the job, and the white guy would get it. The white guy would apply for a house. After the documentary, the people making it confronted one of the guys "cause they looked at two apartments, and they actually confronted the couple, and I was in shock. I thought they were going to show the situation and not really do anything about it, but they took action and actually confronted the guy and his wife, and, you know, I was like, "More people should do that." I know a lot of people do it, and seeing the way these people handled it was like, "I can do it when I know 
something's wrong, maybe I can't prevent it, but I can do something about it after it happens."

In the last reflection, Nancy describes the moment when the class instructor modeled being an ally and how that helped her realize she could be an activist for marginalized groups:

One of the things that stuck out was [the instructor] said, "Raise your hand if you're a feminist." Everybody raised their hands and [the instructor] raised his hand, and I was like, "Why is his hand up?" He [said] you can be male and be a feminist. I didn't even think of that. That's the same as saying, "I can be heterosexual and still be a gay rights activist." I didn't think of it that way. That's something I learned that you don't have to be silent just because you're in the [dominant] group. And speaking out and taking a stand is something that the minority needs.

\section{DISCUSSION AND IMPLICATIONS}

The goal of this study was to explore students' perceptions of how the curriculum and teaching strategies in a social justice education course prepared them for social action engagement. In other words, what are the indicators that students are "ready" or possess the knowledge, attitudes, and skills to engage in social action once they complete a social justice education course? In addition, how does the practice in a social justice education course influence this process? The findings reflect previous studies in that the pedagogy was identified more often than content in helping students meet the action-oriented outcomes in the course (Gurin-Sands et al., 2012; Nagda et al., 2003; Nagda et al., 2009). The pedagogy, specifically experiential activities (e.g., writing a coming out letter, video, action planning), appears to help students develop empathy toward oppressed groups and learn ways to combat acts of oppression. Experiential education is a foundation of social justice pedagogy that requires students to reflect 
on structured activities to help them connect their personal experiences to topics discussed in the classroom (Adams, 2010). Having students reflect on their experiences and their classmates' experiences with the "isms" may increase their empathy and their willingness to take action. Some scholars argue that there is a relationship between empathic concern and helping others (Stephan \& Finlay, 1999). In addition, sharing their action plans and viewing others taking action can help students reflect on the benefits and the risks of social action engagement. This may help students feel greater change agency or feel more prepared when faced with acts of social oppression in their daily lives.

The principles of social justice pedagogy might explain other findings. For instance, students mentioned trust, emotion, and real-life experiences when discussing the importance of lived experiences. SJE pedagogy validates the relationship between emotion and learning and places emphasis on developing group guidelines in the classroom to develop a safe environment where students can discuss how social oppression has affected their lives (Adams, 2010). Targeting both the cognitive and affective elements of student learning may lead to greater understanding about social oppression (Romney, Tatum, \& Jones, 1992). Also, SJE pedagogy encourages students to make connections between their personal experiences and societal issues (Adams, 2010). The process of "connecting the personal with the institutional” (Zúñiga, Nagda, \& Sevig, 2002, p. 13) can help students recognize the "isms" in their daily lives and develop greater understanding of the need for social action engagement. Through reflection and sharing their lived experiences in the classroom, students can make the "isms" real for one another. Nagda et al. (2004) argue that "first person narratives" may help students "appreciate the impact of prejudice and discrimination on people they know... and feel compelled to promote diversity and interrupt others' prejudices" whereas the content in SJE courses may help them understand 
social injustice primarily on an "abstract level" (p. 209). One classroom implication is that social justice educators have to assess whether they are privileging abstract conceptualization over active experimentation in their courses (Kolb, 1984). Social justice education courses that provide students the opportunity to engage in social action behaviors while enrolled may help students increase their understanding of abstract concepts, ability to recognize "isms" in their daily lives and confidence to take action (Lopez, Gurin, \& Nagda, 1998). Furthermore, students can learn the change process while actually working toward equity.

Students reported both content and pedagogy as factors raising their personal awareness and confidence to take action. Teaching students about the interlocking system of oppression increases their awareness about the complexity of social inequality in society and provides them with information necessary to educate others, as Erica mentioned in her reflection. According to Hackman (2005), "Without complex sources of information, students cannot possibly participate in positive, proactive social change" (p. 104).

The confidence theme reflects and contradicts previous research. Nagda et al. (2004) found that students who enrolled in social justice education courses were more confident to take action by the end of the semester. However, Alimo (2012) found no significant difference in confidence between students enrolled in the dialogue course and the control group course in which similar content and pedagogy was used. The classroom implication is that social justice education courses that require students to read and dialogue about social justice issues only may lead to hopelessness and despair among students (Hackman, 2005. Social justice educators must provide students with the tools necessary to work toward equity and justice and provide them with the opportunity to use those tools to increase their confidence to engage in social action. The 
previous studies did not provide information indicating whether students were provided with opportunities to engage in social action while enrolled in social justice education courses.

The findings in the current study raised several tensions and questions. The focus of change discussed in social justice education courses is at both the micro- and macro-level. However, students' responses reflected change at an individual level and were primarily selfdirected. One question is: Do students feel "ready" to engage in social action on a macro-level after enrolling in a social justice education course or only at a micro-level? Also, actions that students reported were self-oriented (i.e., challenging one's own prejudice). While this is necessary for students to be effective allies and change agents, do students feel prepared to challenge their peers, families, and others on the broader spectrum of their sphere of influence? The classroom implications for social justice educators may be that macro-level social action needs to be introduced at the beginning of the semester instead of the end of the course and students need to be provided with opportunities to conduct a social action project that demonstrates their understanding of macro-level action. For example, there are several recent studies that explore the effectiveness of using case studies or vignettes that examine real life social justice incidents on both the micro- and macro-level (see Burrell, 2008; Darvin, 2011). In each case a pre/post design was used that allowed the instructors to introduce the vignettes in the beginning of the semester and use them as teaching tools (e.g., role plays) to help students learn the change process. Both authors argue that this process can help students prepare to engage in social action. To extend students' learning beyond the vignettes (that serves as a proxy for social action), I contend that students conduct a social action project they design and implement collaboratively during the semester. This would allow students to demonstrate their preparedness for social action and to apply the principles and practice of social justice education (e.g., content 
mastery, critical thinking skills, tools for social action, collaboration) needed to be effective change agents.

While examining the relationship between student enrollment in social justice education courses and action-oriented outcomes is a promising area for further research, there are several limitations in this study. The first limitation is that I relied solely on self-reports, which can be hindered by students' memory. I recommend that future studies assess students' ability to demonstrate their learning on action-oriented outcomes, such as designing and implementing a social justice action project (Pittman, 2009). In addition, the sample size was small and the students who agreed to be interviewed reported having "positive" experiences in the course. I encourage future studies to increase the sample size to gain a broader perspective on this topic. Also, the interviews took place one semester after students enrolled in the SJE course. I recommend that future studies conduct student interviews at the end of the course and the following semester to compare their responses and to determine whether changes were longterm.

I believe these findings provide social justice educators with possible indicators of students' readiness for social action engagement, especially when compared to current literature. These findings provide social justice educators with information to consider if preparing students for social action engagement is an outcome for their course. Helping students develop the knowledge, skills, self-confidence, and motivation necessary for positive social engagement with issues of social justice and diversity is a growing need for our increasingly diverse society. If we social justice educators intend to walk our talk, we must design curricula and incorporate practice into our classrooms that promote praxis and prepare students to enact our democratic values in their daily lives. 


\section{REFERENCES}

Adams, M. (2007). Pedagogical frameworks for social justice education. In M. Adams, L. A. Bell, \& P. Griffin (Eds.), Teaching for diversity and social justice (2 ${ }^{\text {nd }}$ ed., pp. 15-30). New York, NY: Routledge.

Adams, M., \& Marchesani, L. (1997). Multiple issues course overview. In M. Adams, L. A. Bell, \& P. Griffin (Eds.), Teaching for diversity and social justice (pp. 261-275). New York, NY: Routledge.

Adams, M. (2010). Social justice education. In D. J. Christie (Ed.), The encyclopedia of peace psychology (pp. 1033-1036). Malden, MA: Wiley-Blackwell.

Alimo, C. (2012). From dialogue to action: The impact of cross-race intergroup dialogue on the development of white college students as racial allies. Equity \& Excellence in Education, 45(1), 36-59.

Banks, J. (2010). Approaches to multicultural curriculum reform. In J. A. Banks \& C. A. Banks (Eds.), Multicultural education: Issues and perspectives (7th ed., pp. 233-256). Hoboken, NJ: Wiley.

Bell, L. A. (2007). Theoretical foundations for social justice education. In M. Adams, L. A. Bell, \& P. Griffin (Eds.), Teaching for diversity and social justice (2 ${ }^{\text {nd }}$ ed., pp. 1-14). New York, NY: Routledge.

Bell, L. A., \& Griffin, P. (2007). Designing social justice education courses. In M. Adams, L. A. Bell, \& P. Griffin (Eds.), Teaching for diversity and social justice (2nd ed., pp. 67-87). New York, NY: Routledge. 
Burrell, S. L. (2008). Assessing the effect of a diversity course on college students' readiness for social action engagement. Unpublished dissertation. University of Massachusetts Amherst.

Carlisle, L. R., Jackson, B. W., \& George, A. (2006). Principles of social justice education: The social justice education in schools project. Equity and Excellence in Education, 39(1), 5564.

Checkoway, B. (2001). Renewing the civic mission of the American research university. Journal of Higher Education, 72(2), 125-147.

Creswell, J. W. (2008). Research design: Qualitative, quantitative, and mixed methods approaches $\left(3^{\text {rd }}\right.$ ed.). Thousand Oaks, CA: Sage.

Darvin, J. (2011). Situated performances in a graduate teacher education course: An inquiry into the impact of cultural and political vignettes (CPVs). Teachers and Teaching: Theory and Practice, 17(3), 345-364.

Grant, C., \& Sleeter, C. (2010). Race, class, gender, and disability in the classroom. In J. A. Banks \& C. A. Banks (Eds.), Multicultural education: Issues and perspectives (7th ed., pp. 233-256.). Hoboken, NJ: Wiley.

Griffin, P., \& Ouellett, M. L. (2007). Facilitating social justice education courses. In M. Adams, L. A. Bell, \& P. Griffin (Eds.), Teaching for diversity and social justice (2 $2^{\text {nd }}$ ed., pp.89113). New York, NY: Routledge.

Gurin-Sands, C., Gurin, P., Nagda, B. A., \& Osuna, S. (2012). Fostering a commitment to social action: How talking, thinking, and feeling make a difference in intergroup dialogue, Equity \& Excellence in Education, 45(1), 60-79. 
Hackman, H. W. (2005). Five essential components for social justice education. Equity and Excellence in Education, 38(2), 103-109.

Hardiman, R., Jackson, B., \& Griffin, P. (2007). Conceptual foundations for social justice education. In M. Adams, L. A. Bell, \& P. Griffin (Eds.), Teaching for diversity and social justice ( $2^{\text {nd }}$ ed., pp.35-66). New York, NY: Routledge.

Kolb, D. A. (1984). Experiential learning: Experience as the source of learning and development. Englewood Cliffs, NJ: Prentice Hall.

Lopez, G., Gurin, P., \& Nagda, B. A. (1998). Education and understanding structural causes for group inequalities. Political Psychology, 19(2), 305-329.

Mayhew, M. J., \& Fernández, S. D. (2007). Pedagogical practices that contribute to social justice outcomes. The Review of Higher Education, 31(1), 55-80.

McAllister, G., \& Irvine, J. J. (2002). The role of empathy in teaching culturally diverse students: A qualitative study of teachers' beliefs. Journal of Teacher Education, 53(5), 433-443.

Miles, M. B., \& Huberman, A. M. (1994). Qualitative data analysis: An expanded sourcebook ( $2^{\text {nd }}$ ed.). Thousand Oaks, CA: Sage.

Nagda, B. A., Gurin, P., \& Lopez, G. E. (2003). Transformative pedagogy for democracy and social justice. Race Ethnicity and Education, 6(2), 165-191.

Nagda, B. A., Gurin, P., Sorenson, N., Gurin-Sands, C., \& Osuna, S. M. (2009). From separate corners to dialogue and action. Race and Social Problems, 1(1), 45-55.

Nagda, B. A., Kim, C.-W., \& Truelove, Y. (2004). Learning about difference, learning with others, learning to transgress. Journal of Social Issues, 60(1), 195-214. 
Nelson Laird, T. F., Engberg, M. E., \& Hurtado, S. (2005). Modeling accentuation effects: Enrolling in a diversity course and the importance of social action engagement. The Journal of Higher Education, 76(4), 448-476.

North, C. E. (2006). More than words? Delving into the substantive meaning(s) of "social justice" in education, Review of Educational Research, 76(4), 507-535.

Orfield, G., \& Lee, C. (2006). Racial transformation and the changing nature of segregation. Cambridge, MA: The Civil Rights Project at Harvard University.

Patton, M. (2002). Qualitative research and evaluation methods ( $3^{\text {rd }}$ ed.). Thousand Oaks, CA: Sage.

Pittman, C. T. (2008). The relationship between social influence and social justice behaviors, Current Research in Social Psychology, 13(20), 243-254.

Pittman, C. T. (2009). Multicultural education and social justice actions. Intercultural Education, 20(2), 173-186.

Quaye, S. J., \& Harper, S. R. (2007). Faculty accountability for culturally inclusive pedagogy and curricula. Liberal Education, 93(3), 32-39.

Romney, P., Tatum, B., \& Jones, J. (1992). Feminist strategies for teaching about oppression: The importance of process. Women's Studies Quarterly, 20(1/2), 95-110.

Rossman, G. B., \& Rallis, S. F. (2003). Learning in the field: An introduction to qualitative research $\left(2^{\text {nd }}\right.$ ed.). Thousand Oaks, CA: Sage.

Seidman, I. (2006). Interviewing as qualitative research: A guide for researchers in education and the social sciences ( $3^{\text {rd }}$ ed.). New York, NY: Teachers College Press.

Smith, S. (2005). Proving diversity classes make a difference: Effective assessment of students' learning. In M. L. Ouellett (Ed.), Teaching inclusively: Resources for course, department 
and institutional change in higher education (pp. 421-434). Stillwater, OK: New Forums Press.

Stake, J. E., \& Hoffmann, F. L. (2001). Changes in student social attitudes, activism, and personal confidence in higher education: The role of women's studies. American Educational Research Journal, 38(2), 411-436.

Stephan, W., \& Finlay, K. (1999). The role of empathy in improving intergroup relations. Journal of Social Issues, 55(4), 729-743.

Zúñiga, X., Nagda, B. A., \& Sevig, T. D. (2002). Intergroup dialogues: An educational model for cultivating engagement across differences. Equity \& Excellence in Education, 35(1), 717.

Zúñiga, X., Williams, E. A., \& Berger, J. B. (2005). Action-oriented democratic outcomes: The impact of student involvement with campus diversity. Journal of College Student Development, 46(6), 660-678. 
Table 1

Participant Demographic Information: Interviews

\begin{tabular}{|l|l|l|l|l|l|}
\hline Name & Race/Ethnicity & Gender & Year in School & $\begin{array}{c}\text { Prior } \\
\text { Course }\end{array}$ & Major \\
\hline Erica & $\begin{array}{l}\text { Black/African } \\
\text { American }\end{array}$ & Female & Junior & No & Psychology \\
\hline Ryan & Asian & Male & Sophomore & No & Biochemistry \\
\hline Dina & Latina & Female & Sophomore & Yes & Communication \\
\hline Oscar & Puerto Rican & Male & Sophomore & Yes & Psychology \\
\hline Kevin & White/Caucasian & Male & Sophomore & Yes & Pre-Business \\
\hline Nancy & White Caucasian & Female & Sophomore & No & Undeclared \\
\hline
\end{tabular}

1 Based on the conceptual framework found in Adams, Bell, and Griffin, 1997, 2007.

2 The purpose of the larger study was to assess the effectiveness of a social justice education course in increasing students' readiness for social action engagement. The primary method for the assessment was an analysis of students responses to a series of two vignettes administered at the beginning and end of the course. In addition, six students were interviewed about the course processes, activities, goals and objectives that they believe are most effective in increasing their readiness for social action engagement (Burrell, 2008).

3 Student is referring to Readings for Diversity and Social Justice ( $2^{\text {nd }}$ ed.) by Adams, Blumenfeld, Castañeda, Hackman, Peters, \& Zúñiga, 2010.

4 I define change agency as students developing confidence to enact change or take social and political actions. 